\title{
Is it possible to operate four heart valves in a patient with heart failure, congenital heart disease and pulmonary hypertension?
}

\author{
Marie Zvěřinováa, Jana Popelováa,c, Petr Pavel ${ }^{a}$, Roman Gebauer, ${ }^{a, c}$, \\ Pavel Jehličkaa, Miroslav Rubáček ${ }^{a}$, Milan Čech ${ }^{b}$, Štěpán Černýa
}

a Kardiocentrum, Nemocnice Na Homolce, Praha, Česká republika

b Interní oddělení, Nemocnice Na Homolce, Praha, Česká republika

' Dětské kardiocentrum, Fakultní nemocnice Motol, Praha, Česká republika

INFORMACE O ČLÁNKU

\section{Historie článku:}

Došel do redakce: 28. 5. 2012

Přepracován: 28. 8. 2012

Přijat: 1. 9. 2012

Dostupný online: 7. 9.2012

\section{Keywords:}

Heart failure

Operation of adult with congenital heart disease

Pulmonary hypertension

Sildenafil

Tetralogy of Fallot

Klíčová slova:

Fallotova tetralogie

Plicní hypertenze

Operace vrozené srdeční vady

$v$ dospělosti

Sildenafil

Srdeční selhání

\begin{abstract}
We describe a 60-year-old man with the history of radical correction of the tetralogy of Fallot (TOF) in the year 1964. This patient has had a long lasting decompensation of a severe right heart failure with ascites and pulmonary hypertension. On echocardiography he had residual mild pulmonary stenosis (PS) and severe pulmonary and tricuspid regurgitation (TR), moderate aortic and mitral regurgitation. He also had residual ventricular septal defect (VSD) and severe pulmonary hypertension with the maximal gradient on TR $83 \mathrm{mmHg}$. He was considered unoperable by his cardiologist, however, the patient decided to undergo a high-risk operation. The operation comprised pulmonary and aortic valve replacement with bioprosthesis, mitral and tricuspid repair, closure of ventricular septal defect, bilateral MAZE and volumereduction of both atria. After a very complicated postoperative course with multiorgan failure he recovered and was discharged home 2 months after operation. The NYHA class improved from IV before operation to II. Twenty months after this operation he experienced infective endocarditis with a leak on the aortic bioprosthesis. He was reoperated with reimplantation of a new aortic bioprosthesis and with a very complicated postoperative course. Sildenafil was added to his therapy due to the persistent severe pulmonary hypertension. He survived and was discharged home. The presented unique high-risk complex reoperation of a congenital heart disease with pulmonary hypertension can be performed only by a very experienced cardiosurgical and cardio-anesthesiological team with a high level of the early and late postoperative care.
\end{abstract}

\section{SOUHRN}

Autoři popisují případ 60letého pacienta s anamnézou radikální korekce Fallotovy tetralogie v roce 1964. Pacient měl v posledních letech progredující těžkou pravostrannou kardiální dekompenzaci s ascitem a plicní hypertenzí. Echokardiograficky měl zjištěnu těžkou pulmonální a trikuspidální regurgitaci, středně závažnou aortální a mitrální regurgitaci a reziduální defekt komorového septa s významným levopravým zkratem. Jeho stav byl považován za chirurgicky neřešitelný, avšak pacient se rozhodl podstoupit vysoce rizikovou operaci. Operace zahrnovala náhradu pulmonální a aortální chlopně bioprotézou, plastiku mitrální a trikuspidální chlopně, uzávěr defektu septa komor a oboustranný výkon MAZE s volumredukcí obou síní. Po velmi komplikovaném pooperačním průběhu s multiorgánovým selháním pacient operaci přežil a byl propuštěn domů dva měsíce po operaci. Jeho funkční výkonnost se zlepšila z funkční třídy NYHA IV na třídu NYHA II. Dvacet měsíců po této operaci byl opětovně hospitalizován pro infekční endokarditidu s paravalvární regurgitací na aortální bioprotéze. Během reoperace mu byla vyměněna aortální bioprotéza s následným velmi komplikovaným pooperačním obdobím. Vzhledem k přetrvávající těžké plicní hypertenzi mu byl ke komplexní léčbě přidán i sildenafil. Pacient přežil a byl propuštěn domů. Takto náročná komplexní reoperace vrozené srdeční vady s plicní hypertenzí je unikátní a Ize ji provést pouze za předpokladu velmi zkušeného operačního týmu a nadstandardní kardioanesteziologické i následné intenzivní pooperační péče.

(c) 2012, ČKS. Published by Elsevier Urban and Partner Sp. z o.o. All rights reserved.

Adresa: MUDr. Marie Zvěrinová, Kardiocentrum, Nemocnice Na Homolce, Roentgenova 2, 15030 Praha 5, e-mail: marie.baumelova@seznam.cz DOI: 10.1016/j.crvasa.2012.09.002 


\section{Background}

At present, the survival of children born with a congenital heart disease (CHD) into adulthood exceeds $85 \%$ [1-3]. The reason is probably in the improved intensive care and cardiac surgery in newborns and babies with critical CHD. However, even after successful operation in childhood there is a risk of residual findings. Some of the residual findings (sequelae) are obligatory, e.g. degeneration of homografts or pulmonary regurgitation after the excision or discision of pulmonary valve. Other residua (e.g. residual defects) are due to the insufficient surgical technique, especially in 60's or 70's. Besides that, we can find acquired valve disease in a patient originally treated for CHD. Even severe residual lesions may be clinically silent for a long time. At the time of limiting symptoms the risk of the operation may be already very high. According to our experience, the most important risk factors of mortality in reoperations of adults with CHD are NYHA class III and IV, cyanosis and dysfunction of the right or left ventricle [4].

Tetralogy of Fallot (TOF) is one of the most common cyanotic CHD, it represents $4-10 \%$ of all CHD $[2,3]$. The long-term survival after the corrective surgery in childhood is very good. Approximately $90 \%$ of those who survived operation are still alive after 20-30 years [5-7]. The most common residual finding in TOF is pulmonary regurgitation, less common is pulmonary stenosis or residual ventricular septal defect (VSD) $[2,3,8]$.

We describe a unique case of two reoperations in an older patient with TOF who was considered inoperable because of the severe state with long lasting severe right heart failure, pulmonary hypertension and because of the extent of the surgery. We did not find any similar case report in the literature.

\section{Description of the case}

Our patient was born in 1950 with tetralogy of Fallot. He had radical correction in 14 years, in the year 1964, the
Table 2 - Catheterisation before operation (right and left catheterisation, oxymetry, selective coronarography).

\begin{tabular}{l|l|}
\hline Qp (pulmonary flow) & $9.7 \mathrm{l} / \mathrm{min}$ \\
\hline Qs (systemic flow) & $4.8 \mathrm{l} / \mathrm{min}$ \\
\hline PAP syst./diastol. & $62 / 22 \mathrm{mmHg}$ \\
\hline PAPmean & $34 \mathrm{mmHg}$ \\
\hline PCW & $19 \mathrm{mmHg}$ \\
\hline PVR & $1.5 \mathrm{WU}$ \\
\hline Qp/Qs & $2: 1$ \\
\hline PS: peak gradient & $25 \mathrm{mmHg}$ \\
\hline coronarography & no coronary stenosis \\
\hline
\end{tabular}

PAP - pulmonary arterial pressure; PAPmean - mean pulmonary arterial pressure; $\mathrm{PCW}$ - pulmonary wedge pressure; PS - pulmonary stenosis; PVR - pulmonary vascular resistance; Qp - pulmonary flow; Qs - systemic flow; WU - Wood units.

operation was performed by professor Navrátil in Brno, Czechoslovakia. Residual VSD was found in 1970, but reoperation was not performed because of the high operative risk and small patient's complaints. The reoperation was offered to our patient again in 2002, but he refused. In 2006 he was repeatedly hospitalized because of severe right heart decompensation with repeated ascites evacuation. He had persistent atrial fibrillation and nonsustained ventricular tachycardias (VT). He was referred to Hospital $\mathrm{Na}$ Homolce for implantable cardioverter-defibrillator (ICD) implantation, which was not performed because of the hypocalemia as the possible reason of VT. We performed a thorough reevaluation of all the residual findings and proposed a possibility of a high-risk reoperation.

We performed echocardiography (Table 1) and catheterisation (Table 2). We found a high Doppler CW gradient $(83 / 40 \mathrm{mmHg})$ on a massive tricuspid regurgitation (TR) during the first examination. This finding could imply irreversible pulmonary hypertension and inoperable state. However, the gradient on TR was increased by the residual pulmonary stenosis with the systolic gradient as-

Table 1 - Comparison of the echocardiographic examinations before and after operation.

\begin{tabular}{llll} 
Echographic parameters & ECHO before operation & ECHO before operation & $\begin{array}{l}\text { ECHO after operation } \\
10.1 .2011\end{array}$ \\
\hline LV & 3.12 .2008 & $\mathbf{7 . 4 . 2 0 1 0}$ & $60 / 44 \mathrm{~mm}$ \\
\hline LVEF & $56 / 42 \mathrm{~mm}$ & $53 / 42 \mathrm{~mm}$ & $55-60 \%$ \\
RV & $45-50 \%$ & $45 \%$ & $46 \mathrm{~mm}$ (PLAX) \\
& $45 \mathrm{~mm}$ (PLAX) & $45 \mathrm{~mm}$ (PLAX) & $39 \mathrm{~mm}(\mathrm{~A} 4 \mathrm{CH})$ \\
\hline RVEF & $57 \mathrm{~mm}(\mathrm{~A} 4 \mathrm{CH})$ & $57 \mathrm{~mm}(\mathrm{~A} 4 \mathrm{CH})$ & $40-45 \%$ \\
\hline LA & RV anterior wall $15 \mathrm{~mm}$ & RV anterior wall $14 \mathrm{~mm}$ & $63 \times 77 \mathrm{~mm}$ \\
\hline RA & $40 \%$ & $40 \%$ & $61 \mathrm{~mm}$ in the long axis \\
TR gradient (max/mean) & $81 \times 75 \mathrm{~mm}$ & $100 \times 60 \mathrm{~mm}$ & $34 / 23 \mathrm{mmHg}$ \\
VCI & $94 \times 81 \mathrm{~mm}$ & $93 \times 91 \mathrm{~mm}$ & $26 / 14 \mathrm{~mm}$ \\
\hline
\end{tabular}

A4CH - apical four-chamber view; LA - left atrium; LV - left ventricle; LVEF - left ventricular ejection fraction; PLAX - parasternal long axis projection; RA - right atrium; RV - right ventricle; RVEF - right ventricular ejection fraction; TR - tricuspid regurgitation, $\mathrm{VCl}$ - vena cava inferior. 


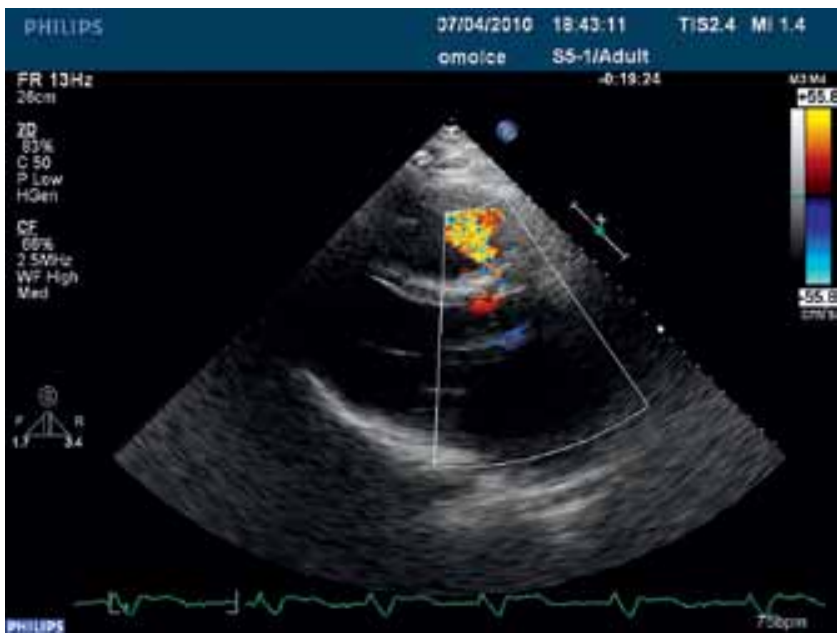

Fig. 1 - Echocardiography, long axis parasternal projection, ventricular septal defect in CFM: left-to-right shunt from left to right ventricle.

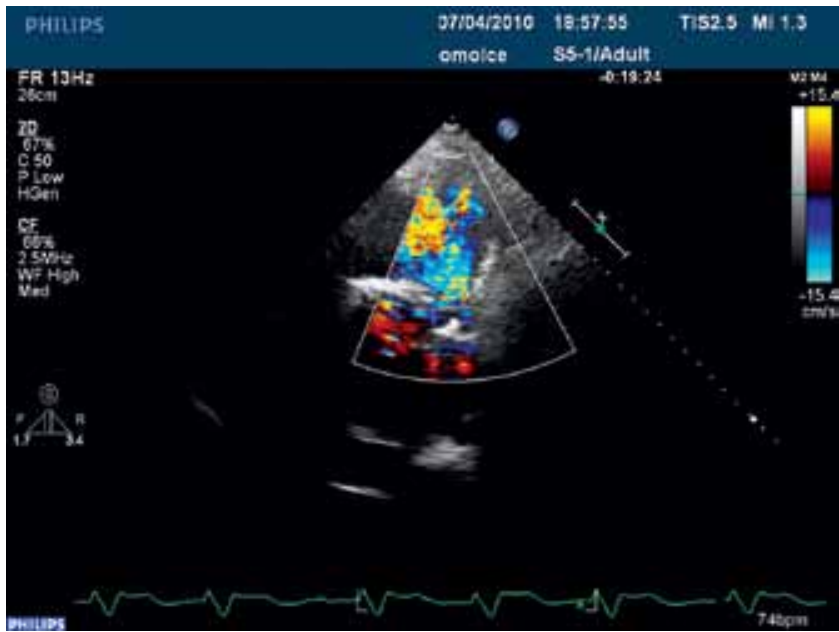

Fig. 2 - Echocardiography, short axis parasternal projection, CFM shows moderate pulmonary regurgitation.

sessed by Doppler $46 \mathrm{mmHg}$. We also found moderate pulmonary, aortic, and mitral regurgitations. The aortic regurgitation was caused by degenerative changes of the leaflets, vena contracta was $5 \mathrm{~mm}$, pressure half time $366 \mathrm{~ms}$ and width of the jet was $15 \mathrm{~mm}(=65 \%$ of the left ventricular outflow tract). Moderate mitral regurgitation was caused by annular dilatation to $46 \mathrm{~mm}$ and a small prolapse of the anterior leaflet, vena contracta was $5 \mathrm{~mm}$. Severe tricuspid regurgitation (Figs. 3, 4) was a consequence of tricuspid annulus dilatation to $50 \mathrm{~mm}$.

The left ventricular end-diastolic diameter (LVEDD) was at the upper level $\left(56 \mathrm{~mm}=27 \mathrm{~mm} / \mathrm{m}^{2}\right)$ with a mild systolic dysfunction. The right ventricle had severe hypertrophy of the wall (14-15 $\mathrm{mm}$ ) and was dilated to $57 \mathrm{~mm}$ with moderately impaired systolic function (Tables 1, 2). Both atria were severely dilated (left atrium $81 \times 75 \mathrm{~mm}$, right atrium $94 \times 81 \mathrm{~mm}$ ).

On the catheterisation we found moderate pulmonary hypertension with the pulmonary arterial pressure (PAP) 62/22; mean $34 \mathrm{mmHg}$, wedge pressure (PCW) $19 \mathrm{mmHg}$, pulmonary arterial resistance 1, 5 Wood units, mild pulmonary stenosis with the peak gradient $25 \mathrm{mmHg}$. After epoprostenol administration (6 $\mathrm{ng} / \mathrm{kg} / \mathrm{min}$ ) there was

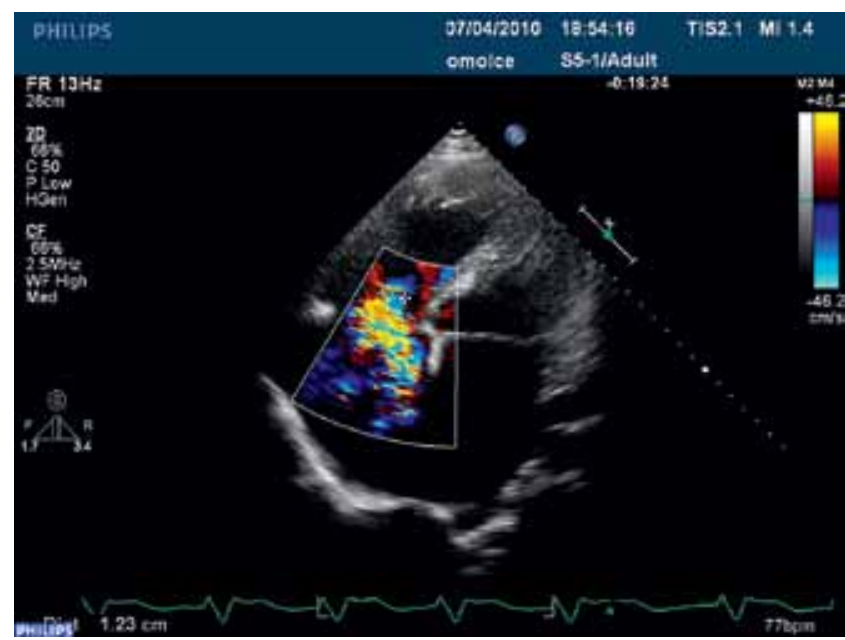

Fig. 3 - Echocardiography, apical four-chamber view (A4C), severe tricuspid regurgitation, vena contracta $12.3 \mathrm{~mm}$.

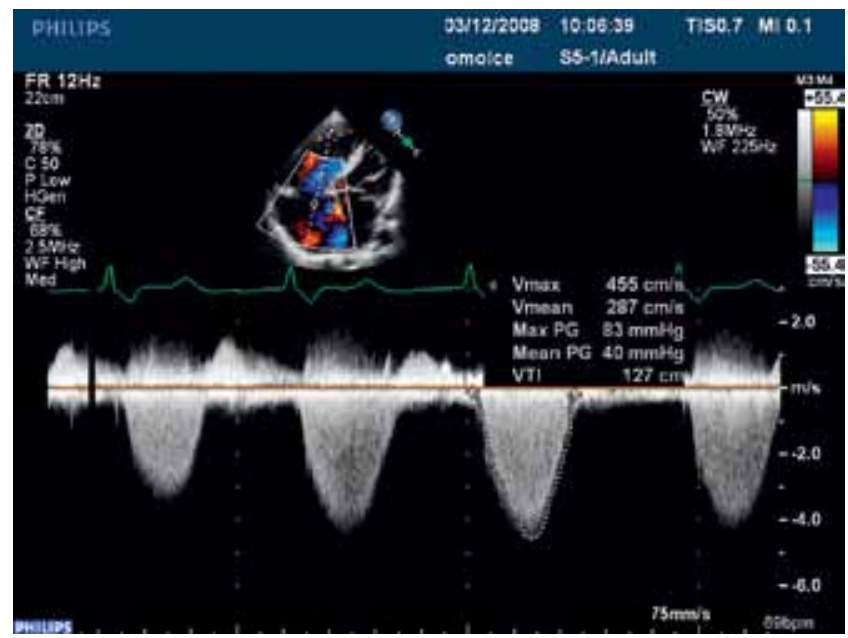

Fig. 4 - CW Doppler, high gradient on tricuspid regurgitation before operation.

a significant reduction of PAP to 37/23; mean $26 \mathrm{mmHg}$ The pulmonary to systemic flow ratio (Qp/Qs) measured by oxymetry was $2: 1$ (Table 2 ).

The definitive diagnosis was hemodynamically significant residual VSD with Qp/Qs 2 : 1 (Fig. 1), severe tricuspid regurgitation, mild pulmonary stenosis, moderate pulmonary, aortic and mitral regurgitation and moderate, mainly postcapillary pulmonary hypertension (Fig. 2).

Our patient was cachectic with large ascites, hepatosplenomegaly, renal insufficiency, diabetes mellitus, chronic obstructive lung disease (heavy smoker) and had the history of bleeding from the duodenal ulcer.

The risk of operation was extremely high, logistic EurOSCORE $37 \%$. However, due to the severe complaints and poor quality of life our patient decided to undergo high-risk operation.

He was operated on 8. 4. 2010 at the Department of Cardiac Surgery in Hospital $\mathrm{Na}$ Homolce. Aortic valve had a prolaps of the left coronary cusp and severe degeneration of the noncoronary cusp and was replaced by a bioprosthesis of the diameter $27 \mathrm{~mm}$. The totally degenerated pulmonary valve was removed and replaced by a bioprosthesis of the diameter $27 \mathrm{~mm}$. It was im- 
planted supraannulary because of the calcification of the right ventricular outflow tract (RVOT). The dilated mitral annulus was repaired by annuloplastic ring of the diameter $34 \mathrm{~mm}$. Afterwards tricuspid annuloplastic ring was given. The residual ventricular septal defect with the diameter of $8 \mathrm{~mm}$ was closed by xenopericardial patch. Furthermore right- and left-sided MAZE (cryoablation) and volumereduction of both atria were performed. The cardiopulmonary bypass time took 368 minutes and aortic cross clamp duration was 293 minutes. At the end of the operation levosimendan and vasopressors were given prophylactically and continuous arterio-venous hemofiltration in citrate was started because of oliguria. The postoperative course was complicated by multiorgan failure, sepsis, and bronchopneumonia. From 14. 5. 2010 the patient was hospitalized at the Intensive and Metabolic Care Unit in the Department of Internal Medicine in Hospital $\mathrm{Na}$ Homolce with complex and intensive nutrition and rehabilitation care. Two months after the operation our patient was able to be discharged home.

In the first half of the year 2011 he was feeling well, without signs of heart failure, and with improved exertion tolerance, he was in NYHA class II. He had sinus rhythm on ECG and good function of both bioprosthesis and repaired valves, no residual ventricular shunt and mild pulmonary hypertension with the calculated PAP systolic/ mean 40/29 mmHg (Fig. 5).

In December 2011 the patient was readmitted to our hospital with infective endocarditis on the aortic bioprosthesis with severe aortic regurgitation due to the leak on the bioprosthesis. The etiologic agent was Enterococcus faecalis, most probably from the residual sacral decubitus. He was septic, with oliguric renal failure, severe cardiac decompensation, severe pulmonary hypertension (from echocardiographic calculation systolic PAP $70 \mathrm{mmHg}$, mean PAP $40 \mathrm{mmHg}$ ), NYHA IV. He had no mitral regurgitation and only mild tricuspid regurgitation. On ECG there was a sinus rhythm without atrial fibrillation recurrence. Because of the critical state, patient was neither catheterized, nor tested for vasodilatation therapy.

On 23. 12. 2011 the patient was reoperated in a very severe state with reimplantation of a new aortic biopros-

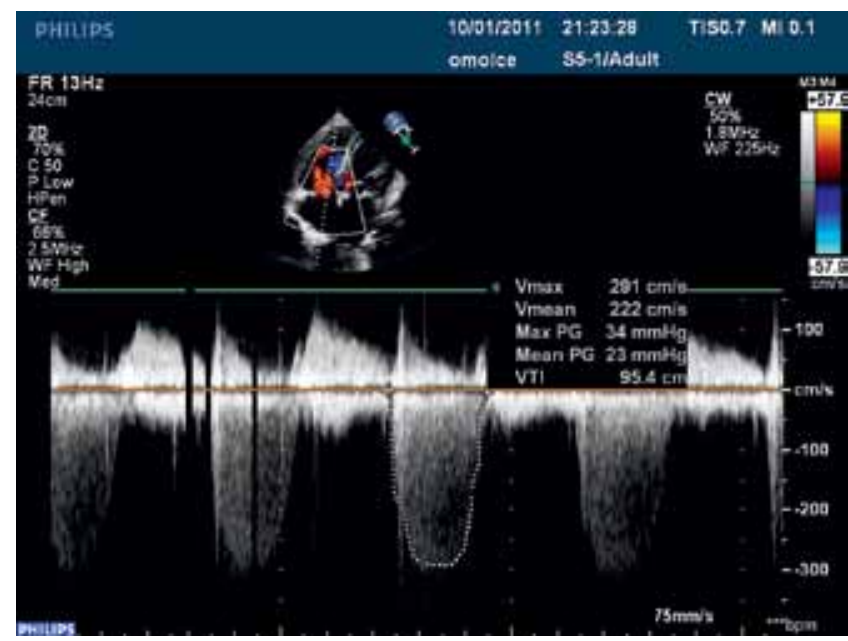

Fig. 5 - Echocardiography: trace tricuspid regurgitation on CFM with decreased CW Doppler gradient after operation. The gradient $34 / 23 \mathrm{mmHg}$ reflects PAP $40 / 29 \mathrm{mmHg}$ (systolic/mean). thesis. Postoperatively levosimendan and Novoseven (recombinant coagulation factor VII) were given. Because of the persistent severe pulmonary hypertension (invasively measured PAP was 79/25, mean $45 \mathrm{mmHg}$ ) iloprost and sildenafil were added. He had continuous veno-venous dialysis in citrate. Later he was transmitted from Cardiac Surgery to Intensive Care Unit in Internal Medicine Department. He was able to leave hospital on 10. 2. 2012 with ambulatory care of the sacral decubitus.

\section{Discussion}

Most adults with TOF have undergone radical surgical correction in childhood. Only rarely we can meet unoperated adult with TOF or a patient with palliative shunt only [10]. The long-term prognosis is good, $92 \%$ of those who survived operation of TOF in childhood reach adulthood in our country [5].

The first radical correction of TOF in the world was performed on cardio-pulmonary bypass by Lillehei in 1954 and Kirklin in 1955. The first radical correction of TOF in the Czech Republic (formerly Czechoslovakia) was performed by Jan Navrátil in Brno in 1961. Our patient was in fact one of the first radically operated patients in our country. At the time of the first operation he was rather old - 14 years. The residua and sequeale of the operations performed in 60's and 70's are relatively frequent. If they do not cause any severe complaints, they may be easily overlooked and may not be solved at the proper time.

Pulmonary regurgitation (PR) is the most common residual finding after radical correction of TOF. The pulmonary valve is often incised, sometimes even excised and in the case of hypoplastic annulus the transannular patch may be used [5]. PR used to be considered for benign lesion, however, there is an association between the severity of PR, dilatation of the right ventricle, prolongation of QRS with right bundle branch block on the ECG over $180 \mathrm{~ms}$ and sudden arrhythmic death [11]. Dilatation and dysfunction of the right ventricle are reversible to certain extent only. Nowadays there is a trend towards earlier correction of the PR in TOF $[8,12]$.

Tricuspid regurgitation (TR) is a secondary lesion due to the dilated right ventricle. If there is no organic cause, it may be repaired, usually with annuloplasty ring.

Aortic regurgitation $(A R)$ can be seldom found before correction of the TOF (in $2 \%$ ). It may be more frequent after the correction [9]. The cause may be in dilated annulus and aortic root of the overriding aorta as well as due to the retraction, perforation, fibrosis or calcification of the aortic cusps, often due to the injury during subaortic VSD closure.

Mitral regurgitation (MR) is not typical for TOF, however, we can find it in some patients due to the dilatation of the mitral annulus, myxomatous changes of the mitral valve and prolapse.

Pulmonary hypertension $(\mathbf{P H})$ is not a part of the TOF. TOF is characterized by low pulmonary flow and low pulmonary pressure before correction. Pulmonary hypertension may be a consequence of a too large aortopulmonary shunt, however, this was not the case of our patient. Our patient had $\mathrm{PH}$ as a result of the combina- 
tion of high pulmonary flow due to the residual VSD and a high pulmonary wedge pressure. However, even after elimination of the VSD and valvular regurgitations, there remained certain degree of pulmonary vascular disease with increased trend to pulmonary vasoconstriction, which could be seen after the second operation. It could be partly corrected by sildenafil. All patients with CHD and echocardiographic suspicion of $\mathrm{PH}$ need a thorough examination, exclusion of pulmonary stenosis and right heart catheterisation with the assessment of pulmonary arterial resistance (PAR) and vasodilatation testing. The specific vasodilating therapy cannot be started in CHD only on the basis of TR gradient. The contraindication for shunt closure in CHD is high PAR (over 7-10 WU or higher than $2 / 3$ of the systemic resistance) $[8,13]$.

TOF is a CHD with the possibility of many residual findings in the long-term follow-up. As we have shown, there may be a dysfunction of all four heart valves besides the residual shunts on ventricular or atrial level. The decision if to operate VSD only or to perform a complex repair of all valves was not easy. Our patient had more reasons for left ventricular volume overload (AR, MR, VSD), but he had only borderline left ventricular dilatation. In our experience it is very difficult to assess the severity of the left-side valve regurgitations in the presence of severe right ventricular dilatation. This is because of the limited space in the pericardial cavity. Our patient had severely dilated right ventricle to $57 \mathrm{~mm}$. Therefore we assumed that the AR and MR may have had hemodynamic significance even without severe left ventricular dilatation. Instead of dilatation there may be increased filling pressure of the left ventricle. That was the reason why we decided to perform a complex repair of all valve lesions besides VSD closure in our patient. The long-term stable sinus rhythm has been achieved by valvular competence, MAZE procedure and volumereduction of the atria.

In Hospital $\mathrm{Na}$ Homolce we performed 12 operations on 3-4 heart valves in patients with CHD in the years 2005-2010 [4]. Three of them had TOF. The operation of 3 or 4 valves represented $2.68 \%$ of all our operations of adults with CHD, one patient from this group did not survive [4].

The hospital mortality in more than 500 operated adults with CHD in Hospital Na Homolce was $1.54 \%$ [4]. This is comparable to other world high volume centers. Good results are dependent on experience, team co-operation, and excellent postoperative care. Even with these good results the decision concerning operation of our patient was difficult because of the severe state, older age, and extent of the surgery. The positive approach of our patient was important. We did not find similar case in the literature.

\section{Conclusion}

The operation of all four heart valves is rare and in connection with complex CHD unique. This high-risk operation was performed in a severely ill patient with severe heart failure and pulmonary hypertension. The operation was successful only due to very experienced surgical and cardio-anesthesiological team and high level of postoperative care. The results of reoperations in adults with CHD are good in specialized, high volume centers.

The question stated in the title could be answered "yes", it is possible.

\section{Acknowledgements}

Supported by the project of Ministry of Health, Czech Republic 00064203.

\section{References}

[1] C.A. Warnes, R. Liberthson, G.K. Danienson, et al., Task force 1: the changing profile of congenital heart disease in adult life, Journal of the American College of Cardiology 37 (5) (2001) 1170-1175.

[2] J. Popelová, E. Oechslin, H. Kaemmerer, et al., Congenital Heart Disease in Adults, Informa Healthcare, London, 2008, pp. 40-50.

[3] J. Popelová, Congenital Heart Disease in Adults (in Czech: Vrozené srdeční vady v dospělosti), Grada Publishing, Praha, 2003, pp. 101-118.

[4] J. Popelová, Š. Černý, R. Gebauer, et al., Six-year experience with cardiac surgery in adults with congenital heart disease (In Czech: Šestileté zkušenosti s operacemi vrozených srdečních vad u dospělých), Časopis lékařů českých 150 (4) (2011) 293-296.

[5] J. Popelová, M. Voříšková, B. Hučín, et al., How are patients faring 30 years after radical tetralogy of Fallot repair? (In Czech: Jak se daří pacientům 30 let po radikální korekci Fallotovy tetralogie?), Cor et Vasa 52 (3) (2010) 154-161.

[6] E.J. Hickey, G. Veldtman, T.J. Bradley, et al., Late risk of outcomes for adults with repaired tetralogy of Fallot from an inception cohort spanning four decades, European Journal of Cardio-thoracic Surgery: Official Journal of the European Association for Cardio-thoracic Surgery 35 (2009) 156-166.

[7] C.W. Lillehei, H. Warden, R. DeWall, et al., The first open heart corrections of tetralogy of Fallot. A 26-31 year follow-up of 106 patients, Annals of Surgery 204 (4) (1986) 490-501.

[8] H. Baumgartner, P. Bonhoffer, N.M. De Groot, et al., ESC Guidelines for the management of grown-up congenital heart disease (new version 2010), European Heart Journal 31 (2010) 2937-2939.

[9] T. Ishizaka, H. Ichikawa, Y. Sawa, et al., Prevalence and optimal management strategy for aortic regurgitation in tetralogy of Fallot, European Journal of Cardio-thoracic Surgery: Official Journal of the European Association for Cardio-thoracic Surgery 26 (2004) 1080-1086.

[10] J. Popelová, F. Kölbel, P. Dostálová, M. Voříšková, Echocardiography in adults with congenital heart disease, Experimental nad Clinical Cardiology 4 (2) (1999) 89-93.

[11] M.A. Gatzoulis, S. Balaji, S.A. Webber, et al., Risk factors for arrhythmia and sudden cardiac death late after repair of tetralogy of Fallot: a multicentre study, Lancet 356 (2000) 975-981.

[12] T. Oosterhof, A. van Straten, H.W. Vliegen, et al., Preoperative thresholds for pulmonary valve replacement in patients with corrected tetralogy of Fallot using cardiovascular magnetic resonance, Circulation 116 (2007) 545-551.

[13] P. Jansa, J. Popelová, H. Al-Hiti, et al., Chronic pulmonary hypertension. Guidelines of the Czech Society of cardiology. (In Czech: Chronická plicní hypertenze. Doporučený diagnostický a léčebný postup České kardiologické společnosti) 2010, Cor et Vasa 53 (3) (2011) 169-182. 